\title{
Relationship between Water Quality and Fish Diversity in Four Rivers of Johor
}

\author{
Vincent Chow Kok Kow ${ }^{1}$, Mohd Ismid Mohd Said ${ }^{1,}$ Maketab Mohamed $^{2}$ and Shaikhah Sabri ${ }^{1}$
}

\begin{abstract}
Status of water quality and fish abundance at four rivers in Johor namely Sungai Mengkibol, Sungai Madek, Sungai Dengar and Sungai Ulu Dengar were investigated. Six parameters of water quality were measured in situ; temperature, conductivity, dissolved oxygen (DO), $\mathrm{pH}$, turbidity and salinity. The results were compared with Malaysia Water Quality Index (MWQI) for river classification. Sungai Mengkibol is located in Kluang Town has been classified as Class III of Water Quality Index (WQI), whereas Sungai Madek, Sungai Dengar and Sungai Ulu Dengar associated with logging, palm oil plantation and forest river respectively classified as Class I of WQI. Despite the poor water quality, the number of fish collected in Sungai Mengkibol was comparable with other sampling stations. However, only tolerant fish species like the Suckermouth Catfish and Short-finned Molly were found abundantly in Sungai Mengkibol. On the other hand, Sungai Ulu Dengar yielded the highest number of fish species (22 species), followed by Sungai Dengar (21 species), Sungai Madek (19 species) and Sungai Mengkibol (11 species). Overall, this study found that the water quality parameters such as DO and temperature were significantly correlated with fish abundance as $r^{2}=0.63$ and 0.5 respectively. Therefore, it can be concluded that the water quality of a river has impact on fish diversity, as certain species are tolerant to changes of the conditions of a river.
\end{abstract}

Keywords--Freshwater fish, Fish abundance, Johor rivers, Water quality

\section{INTRODUCTION}

$\mathrm{A}_{\mathrm{n}}^{\mathrm{c}}$ QUATIC resources are fundamental to livelihood of man and they are a vital component in the well-being of all living organisms be it plants or animals. They are useful or potentially useful to humans, which may be in agricultural, industrial, household, recreational, research, navigation, health and environmental activities. Virtually all of these human uses require freshwater. About $97.5 \%$ of water on the earth is salt water, leaving only $2.5 \%$ as freshwater [1]. Water resources demand already exceed supply in the world and as world population continues to rise at an unprecedented rate, many more imbalances should be expected in the supply of the aquatic resources.

Malaysia is one of the countries that has a wide range of freshwater fishes. Within 1000 species of freshwater species recorded in Southeast Asian tropics, 420 species are known to inhabit Malaysia's river [2].

\footnotetext{
${ }^{1}$ Department of Environmental Engineering, Faculty of Civil Engineering, Universiti Teknologi Malaysia, 81310 Johor Bahru, Johor.

${ }^{2}$ Department of Chemical Engineering, Faculty of Chemical Engineering, Universiti Teknologi Malaysia, 81310 Johor Bahru, Johor.
}

The presence and abundance of fish in any habitat are closely associated with the physiochemical properties of water, land use activities and physical component of the river. Therefore, fish can be utilized as indicator to reflect the habitat condition particularly river ecosystem. The freshwater fish are recognized to be a good indicator of water quality in the river system owing to their sensitivity and response towards stressors [3]. However, in Malaysia, the fish species are being increasingly threatened by habitat modification, contamination and overfishing [4]. To date, there are limited documented studies on freshwater fish species especially in Johor's river. Therefore, this study aimed to investigate the correlation between fish abundance with water quality of the rivers. Determination of fish requirements provides useful information concerning the survival of the fish population.

\section{METHODOLOGY}

Samples of water and ichthyofauna were collected in 2008 to 2010 from four sampling stations located within the Sungai Endau watershed area in the districts of Kluang, Segamat and Mersing in the state of Johor. Sungai Madek, Sungai Mengkibol, Sungai Dengar and Sungai Ulu Dengar were selected for the study are in the Order 2 and 3 category and are mainly wadeable rivers. These criteria are mainly to enable ease of sampling of fish by using the electro-fisher. In addition, the sites are all within a catchment spread that could be assessed easily.

At each station, six in-situ parameters were determined; temperature, conductivity, dissolved oxygen (DO), $\mathrm{pH}$, turbidity and salinity. A multi-meter probe Model Yellow Springs Instrumentation (YSI) 6920 with 650 MDS Display/ Logger as well as single parameter probe were used for in-situ testing of water quality. Whereas, seven parameters of water quality were measured in the laboratory namely biochemical oxygen demand (BOD), suspended solids (SS), phosphate, nitrate and sulphate, chermical oxygen demand (COD) and ammoniacal nitrogen (AN). The resultes were then reffered to the Water Quality Index for river classification, from Class I to Class V.

On the other hand, ichthyofaunal sampling was conducted in situ with the assistance of three assistants, with one wielding the electro-fisher, while two others followed to scoop up stunned fishes. Sampling was conducted by wading from downstream to upstream to avoid disturbing the stream clarity. The handler of the 
electro-fisher moved on a left to right along the river and back in a zig-zag manner for better coverage for each reach. All stunned fish were scooped up as fast as possible. Drifted fishes caught in the mesh net lower down the sampling reach were also collected. Measurement of total length and weight were conducted immediately after each sampling round. All fish caught were identified down to species level using standard taxonomic keys following [5] and [6] and the numbers of individual per species were counted. Total length( TL in $\mathrm{cm}$ ) of each fish was measured using measuring board and the wet weight $(\mathrm{g})$ of each species were collectively taken using digital balance model METTLER BD 1201 to the nearest centimetre and gram respectively.

All statistical analysis were completed using Statistical Package for Social Sciences (SPSS) software version 16.0. One-way analysis of variance (ANOVA) was used to determine the statiscally significant difference of each test. Detailed explanation of each mean analysis among the group was using post hoc test using Turkey's test. Level of significance was set at 95\% ( $\mathrm{p}<0.05)$ to reject null hypothesis. In the study null hypothesis was presumed as there will be no difference between group at all sampling stations.

\section{RESUlt AND DisCUSSIONS}

\subsection{Fish Assemblages}

A total of 1124 adult and juvenile individuals, representing 35 species from 13 families were collected in four rivers of Johor. The highest number of fish were collected at Sungai Dengar station (376 individuals) followed by Sungai Ulu Dengar (306 individuals), Sungai Madek (238 individuals) and Sungai Mengkibol (204 individuals). However, there were no significant difference found between stations for the fish abundance as the one way ANOVA shows $p=0.138, p>0.05$.

Families that dominated were Cyprinidae with 20 species, followed by Mastacembelidae with three species, Channidae and Hemiramphidae with 2 species each. The other families were represented with one species like Bagridae, Cichlidae, Claridae, Cobitidae, Gobiidae, Loricariidae, Poecilidae, Sisoridae and Synbranchidae. Among the families, the Cyprinidae comprised the highest number of species as they are the most common species found in Malaysia's rivers. This was similar with previous studies recorded by [7] and [2] in Sungai Pahang and Sungai Perak respectively. The dominance of Cyprinidae could probably be due to the high adaptive variability and availability of extensive heterogeneous habitat structure in Malaysia's river. Sungai Ulu Dengar has the highest number of species with 22 species, followed by Sungai Dengar with 21 species and Sungai Madek with 19 species. The lowest number of species was recorded at Sungai Mengkibol with 11 species. This study obtained less number of species compared with previous study that found 13 species at Sungai Mengkibol [8]. Among 35 species, only three species were present at all sampling stations, Labiobarbus leptocheilus (Long-finned Shark Barb),
Osteochilus vittatus (Silver Sharkminnow) and Rasbora dusonensis (Yellowtail Rasbora). The presence of these species in all sampling stations indicated that these three species are quite tolerant and well adapted to environmental changes like water quality [2].

\subsection{Water Quality}

The physical parameters of water samples at sampling station are presented in Figure 1, while Table 1 shows the concentrations of each parameter and river classification based on Water Quality Index (WQI). Overall, Sungai Mengkibol has been classified under Class III of WQI whereas Sungai Madek and Sungai Dengar can be classified as Class I river. Earlier, study conducted by [8] indicates that Sungai Mengkibol and Sungai Dengar are under Class IV and II respectively. Poor water quality recorded in Sungai Mengkibol is probably associated with anthropogenic contamination as Sungai Mengkibol is located in Kluang town compared with Sungai Madek and Sungai Dengar which are located in logging area and palm oil plantation. Moreover, degradation of water quality at Sungai Mengkibol could have been influenced by industrial waste water discharges and agricultural activities located upstream of the sampling station [9].

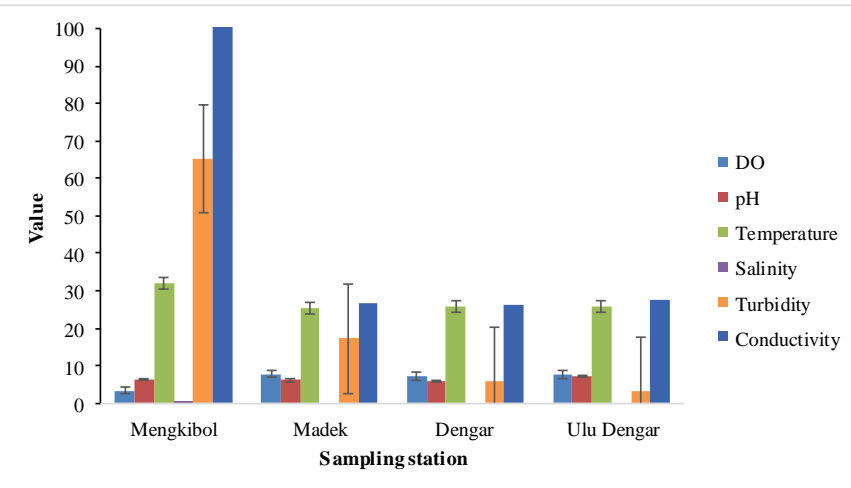

Fig. 1: Average Water Quality At Sampling Station From 2008 To 2010

TABLE I

AVERAGE WATER QUALITY AND COMPARISON WITH WATER QUALITY INDEX (WQI)

\begin{tabular}{|l|l|l|l|l|}
\hline $\begin{array}{l}\text { Parameter/Water } \\
\text { Quality Index }\end{array}$ & \multicolumn{4}{|c|}{ Sampling Station } \\
\cline { 2 - 5 } $\begin{array}{l}\text { Dissolved } \\
\mathrm{mg} \text { L }\end{array}$ & Mengkgibol & Madek & Dengar & Ulu Dengar \\
\hline $\mathrm{pH}$ & $3.37 \pm 0.62$ & $7.80 \pm 0.47$ & $7.30 \pm 0.67$ & $7.59 \pm 0.43$ \\
\hline Temperature, ${ }^{\circ} \mathrm{C}$ & $6.42 \pm 0.38$ & $6.10 \pm 0.82$ & $5.86 \pm 0.95$ & $7.14 \pm 0.61$ \\
\hline Turbidity, NTU & $32.06 \pm 2.09$ & $25.37 \pm 0.89$ & $25.64 \pm 0.78$ & $25.85 \pm 1.22$ \\
\hline Conductivity, $\mu \mathrm{S}$ & $524.95 \pm 39.75$ & $17.14 \pm 9.63$ & $6.02 \pm 1.12$ & $3.15 \pm 1.01$ \\
\hline Salinity, ppt & $0.23 \pm 0.17$ & $26.76 \pm 2.60$ & $26.28 \pm 2.59$ & $27.70 \pm 1.88$ \\
\hline WQI & NT & NT & NT \\
\hline
\end{tabular}

NT: Not tested

\subsection{Correlation between Water Quality and Fish} Assemblages

Sungai Mengkibol shows the lowest concentration $(3.37 \mathrm{mg} / \mathrm{L})$ of dissolved oxygen (DO) in comparison with other stations. Furthermore, one-way ANOVA showed that the concentration of DO in the Sungai Mengkibol was significantly different $(\mathrm{p}=0 ; \mathrm{p}<0.05)$ compared to other rivers. The average concentration obtained in this study was comparable with [11] where the DO ranged from 2.21 
to $4.75 \mathrm{mg} / \mathrm{L}$. Sungai Ulu Dengar shows a high value of $\mathrm{pH}$ (7.14) compared with the other stations. However, statistical analysis showed no significant difference in $\mathrm{pH}$ values found between stations where $\mathrm{p}=0.065, \mathrm{p}>0.05$. Moreover, a high number of fish was collected at high concentrations of DO as shown in Figure 2. There was a significant correlation observed as $\mathrm{r} 2=0.63$.

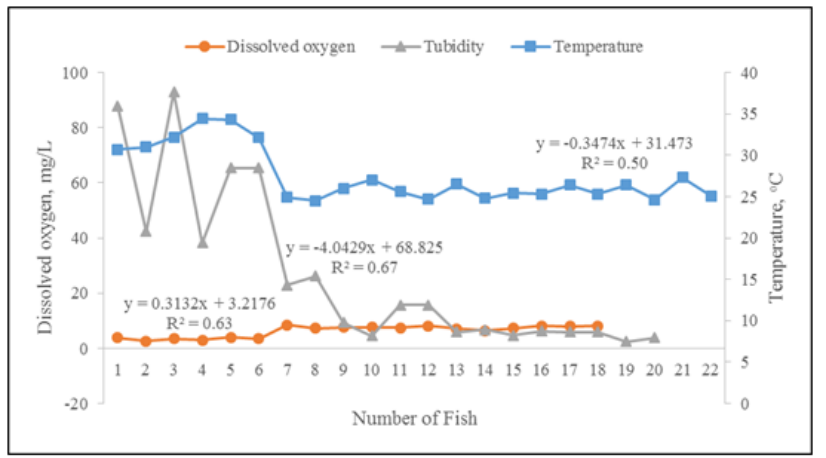

Fig 2: Correlation Of Water Temperature, Dissolved Oxygen And Turbidity With Number Of Fish At Sampling Station

Temperature values ranged from 25.37-32.06 oC. One way ANOVA test indicates that temperature at Sungai Mengkibol was significantly higher than other rivers $(p=0$, $\mathrm{p}<0.05$ ), whereas there were no significant difference of temperature in Sungai Madek, Sungai Dengar and Ulu Dengar where $\mathrm{p}=1, \mathrm{p}>0.05$.Generally, there are many factors that influence temperature such as weather condition, time of sampling and location which influence the DO, biological activities and other parameters [12]. Correlation between water temperature and number of fish collected at sampling station was quite significant with $\mathrm{r} 2=$ 0.5 (Figure 2). The cold water of Sungai Ulu Dengar and Sungai Dengar is favourable to Long-finned Shark Barb and Siamese Algae Eater, whereas the warm water of Sungai Mengkibol is favourable to Suckermouth Catfish and Short-finned Molly.

On the average, there were no significant differences (one way ANOVA test, $p>0.05)$ in conductivity $(p=1)$ and turbidity $(\mathrm{p}=0.67)$ between stations of Sungai Madek, Sungai Dengar and Sungai Ulu Dengar. However, Sungai Mengkibol shows a significant difference of turbidity $(\mathrm{p}=$ $0.01 ; \mathrm{p}<0.05)$ and conductivity $(\mathrm{p}=0.00 ; \mathrm{p}<0.05)$ compared to other stations. Through observations, Sungai Mengkibol has murkier water compared with the other sampling stations. Murky river water is normally caused by the presence of suspended particles like silt, clay, organic matter or plankton [13].

\section{CONCLUSION}

This study suggested that the fish species diversity is closely related to the water quality of the rivers. Sungai Mengkibol was found to have comparable number of fish with other stations despite its low water quality and less habitat components of the river. This indicated that certain species of fish are tolerable to the impaired ecosystem. Species like Suckermouth Catfish, known for their ability to survive in extreme condition, was found abundantly at Sungai Mengkibol.

\section{REFERENCES}

[1] A. Woldai, Multi-stage flash desalination: Modeling, simulation and adaptive control, United States of America: CRC Press, 2015.

[2] Z. H. Hashim, R. Y. Zainuddin, A. S. R. M. Shah, S. A. M. Sah, M. S. Mohammad, and M. Mansor, "Fish checklist of Perak River, Malaysia." Journal Species Lists and Distribution, vol. 8, pp. 408413, 2012.

[3] E. Lopez-Lopez, and J. Sederio-Diaz, "Biological indicators of water quality: The role of fish and macroinvertebrates as indicators of water quality," Environmental Indicator, pp. 643-661. (2015).

[4] V. C. Chong, P. K. Y. Lee, and C. M. Lau, "Diversity, extinction risk and conservation of Malaysia fishes," Journal of Fish Biology, Vol. 76, pp 2009-2066, 2010. http://dx.doi.org/10.1111/j.1095-8649.2010.02685.x

[5] A.K.M. Mohsin, and M.A. Ambak, "Freshwater fishes of Peninsular Malaysia," Penerbit Universiti Pertanian Malaysia, Malaysia, 1983

[6] S. C. Hua, "A field guide to the fish of Tasek Bera Ramsar Site, Pahang Malaysia," presented at Petaling Jaya: Wetland International Malaysia Programme, 2002.

[7] A. R. Zulkafli, M. N. A. Amal, S. Shohaimi, A. Mustafa, A. H. Ghani, S. Hashim, M. I. Anuar, and M. P. Hasfairi, "Length-weight Relationships of 20 fish species from Pahang River, Maran District, Pahang, Malaysia," Journal of Applied Ichthyology, vol. 31, pp. 409410, 2015. http://dx.doi.org/10.1111/jai.12666

[8] H. Halim, "Water quality and fish habitat assessment of rivers in Johor (Sungai Dengar, Sungai Tui and Sungai Mengkibol)," M.S. thesis, Universiti Teknologi Malaysia, 2009.

[9] E. A. Rak, Ahmad-Abas, Ismid, Said, S. and M. Mohamad, "Benthic macroinvertebrate composition and diversity in the Mengkibol River, Kluang, Johor, Malaysia," in Proc. The $7^{\text {th }}$ IMT-GT UNINET and the 3dr Joint International PSU-UNS Conference on Bioscience for the Future. Songkla University, Thailand, 2010, pp. 1-18.

[10] N. Z. Arman, Salmiati, M. I. M. Said, and S. Azman, "Anthropogenic influences on aquatic life community and water quality status in Mengkibol River, Kluang, Johor, Malaysia," Journal of Applied Sciences in Environmental Sanitation, vol. 8, pp. 151-160, 2013.

[11] F. Al-Badaii, M. Shuhaimi-Othman, and M. B. Gasim, "Water quality assessment of the Semenyih River, Selangor, Malaysia," Journal of Chemistry, vol. 2013, pp. 1-10, 2013. http://dx.doi.org/10.1155/2013/871056

[12] J. Yisa, and T. Jimoh, "Analytical studies on water quality index of River Landzu." American Journal of AppliedSciences, vol. 7, pp. 453-458, 2010. http://dx.doi.org/10.3844/ajassp.2010.453.458 